\title{
East Canal Flood as PDAM water resource DKI Jakarta
}

\author{
Wednes Suci Pradafitri ${ }^{1, *}$, Setyo Sarwanto Moersidik ${ }^{2 *}$, and Chairil Abdini ${ }^{1}$ \\ ${ }^{1}$ School of Environmental Science, University of Indonesia, Salemba 4, Jakarta \\ ${ }^{2}$ Environmental Engineering, Faculty of Engineering, University of Indonesia, Depok
}

\begin{abstract}
Environmental pollution, resource degradation, and global warming are some examples of environmental problems that have occurred in various countries, including Indonesia. Poor quality, quantity, and continuity of raw water condition make water supply scarce. These problems can be overcome by an intervention to the demand and supply. One of the cities experience this condition is the province of DKI Jakarta. East Flood Canal (BKT) is one of the infrastructure facilities of DKI Jakarta province as a potential source of raw water supply. The study aims to analyze the factors affecting BKT water and the sustainability of BKT water in DKI Jakarta as the raw water source of PDAM in terms of quality. Analysis of land use and social factors using GIS (Geographic Information System) and questionnaire methods. Analysis of the quality of BKT water using laboratory tests and literature studies. The results of this research are socio-economic activity and land use changes affect the water quality of BKT. The East Canal Flood can become the raw water source of PDAM DKI Jakarta through pre-treatment. This research is very important because it provides a new innovation in overcoming the problem of availability of raw water which is increasingly limited especially in DKI Jakarta.
\end{abstract}

\section{Introduction}

Nowadays, environmental issues are a very important issue in the world. Environmental pollution, resource degradation, and global warming are some examples of environmental problems that have occurred in various countries, including Indonesia. This condition of environmental damage occurs due to human activities or activities as well as naturally [7]. Activities and needs of human life in an area increase along with the increase in population. Rapid population growth due to native population and urbanization is common in big cities, one of which is DKI Jakarta. The population of DKI Jakarta which has increased every year has an impact on increasing the need for land for housing and other space facilities to accommodate the activities of the population.

In addition, high anthropogenic activity affects the ecological conditions in the surrounding area, such as changes in land use, water, and living things. A large number of land use

\footnotetext{
* Corresponding author: ssarwanto@eng.ui.ac.id
} 
changes that occur in the DKI Jakarta region causes a reduction in the capacity of the environment to absorb water, resulting in flooding. In overcoming this flood problem, the DKI Jakarta government built an infrastructure that serves as a place to hold water and free the East Jakarta to Northern areas from flooding called the East Flood (BKT). The East Canal Flood is traversed by five rivers, namely Cipinang River, Sunter River, Buaran River, Jati Kramat River, and Cakung River. Data from BBWSCC (2013) states that land use in the BKT region changes due to human socio-economic activities. The area of land to hold rainwater runoff has undergone the conversion of land into settlements, apartments and wild houses. This has an impact on narrowing the river, decreasing the quality of the water, and reducing the quantity and continuity of BKT water.

The BBWSCC report (2013) revealed that the average river water discharge in the BKT area over the past 5 years showed an increase of around $0.021 \mathrm{~m}^{3} / \mathrm{sec} / \mathrm{km}^{2}$. The data can be interpreted BKT has the potential as a raw water source for DKI Jakarta PDAM. The utilization of BKT as a raw water source for PDAM can overcome the problem of water deficit in DKI Jakarta. The BKT water quality conditions exceed the threshold due to domestic waste and not in accordance with raw water standards. The study of environmental impacts during the life cycle, processes, products, technology, and certain activities is needed to solve this condition. This study aims to analyze the factors that affect the quality of BKT water and its sustainability as a raw water source for DKI Jakarta PDAM.

\section{Methods}

The research conducted at upper east flood canal (Cipinang river), east jakarta. The section was chosen because it is the spot of diverted ciliwung river through cipinang river. Data collection methods in this study include primary surveys and secondary surveys. The primary survey was conducted through observation, documentation, and observation of land use in the study area to determine the physical, socio-economic factors affecting the water quality of BKT obtained through questionnaires to residents around BKT sample point, water quality sample of BKT using the method of Indonesian National Standard (SNI) with raw water key parameters according to water class I and II Government Regulation No. 82 of 2001. The secondary survey is the collection data obtained from agencies and literature studies. Data analysis consist of land use analysis method by using Geographic Information System (GIS), analysis of population socio-economic condition, water quality analysis of BKT using laboratory test, and descriptive analysis.

\section{Result and discussion}

The East Canal Flood (BKT) is an infrastructure that was established by the Provincial Government of DKI Jakarta to tackle and realize Jakarta flood-free. It accommodates five rivers in Jakarta, including Cipinang River, Sunter River, Buaran River, Jati River Kramat, and Cakung River. The average flow rate of river water in BKT area for the last 5 years shows an increase of about $0.021 \mathrm{~m}^{3} / \mathrm{s}$ (Ciliwung Cisadane River Basin Area [7]. Based on the report of Ciliwung Cisadane River Basin (BBWS CC), (2013) states that in the area around the river BKT there has been a change of land use. 


\subsection{Socio-economic factors affecting water quality of BKT}

The results of this research and field observation, socio-economic activities in the upstream bkt developed rapidly. Population data obtained for a percentage of length of stay, education, occupation, and basic income. The residents in upstream BKT have lived for more than 20 years with a percentage of $38 \%$. The highest percentage of education level of upstream BKT is high school $(47.9 \%)$. In addition, the majority of principal income per month is $>$ Rp. 4,500,000 (33.8\%). Rapid population growth is followed by increasing human needs, such as a place to live. Type of residential building can affect the degradation of river and land environment quality. Questionnaire results that behaviour pollute bkt respondents do not have adequate domestic waste disposal channel so that the waste is directly charged into the river. The high school education level (SHS), which is equal to $47.9 \%$. The level of education correlates with community knowledge. Environmental knowledge is accessible to influence people's behaviour. Increased knowledge at the high school level related to the environment makes residents around BKT able to explore or exploit resources in the region. Field observations, some ways of utilizing resources upstream of the bkt are not appropriate, thus polluting the environment. This is consistent with the research of [7] that the level of education influences people's attitudes in managing the environment and mitigation efforts.

The next factor is the type of work and principal income each month. In the CP1study area, the majority of the population is low-middle income, and works as a seller of warteg rice and merchants, while in CP 3-4 most of the population earns rp. 4,500,000 and works as teachers and private employees. Economic conditions with low income made residents in the $\mathrm{CP} 1$ region unable to facilitate adequate sewerage in their homes.

\subsection{Physical factors affecting water quality of BKT}

The condition of land use in the upstream area of the east canal flood (cipinang river) based on observations has changed (see Fig. 1.). The change in land use is due to rapid population growth, thus increasing the pressure and resource requirements for human life [5]. Changes in forest land use to non-forests such as agriculture, settlements, industry, plantations, and others, tend to have a negative impact. These negative impacts include erosion, degradation of water quality by pollutants, water scarcity, and run off [3]. The research of [4] discloses that land use change is directly related to food security, health, urbanization, loss of biodiversity, migration, environmental preservation, water quality, runoff water, and sedimentation. 


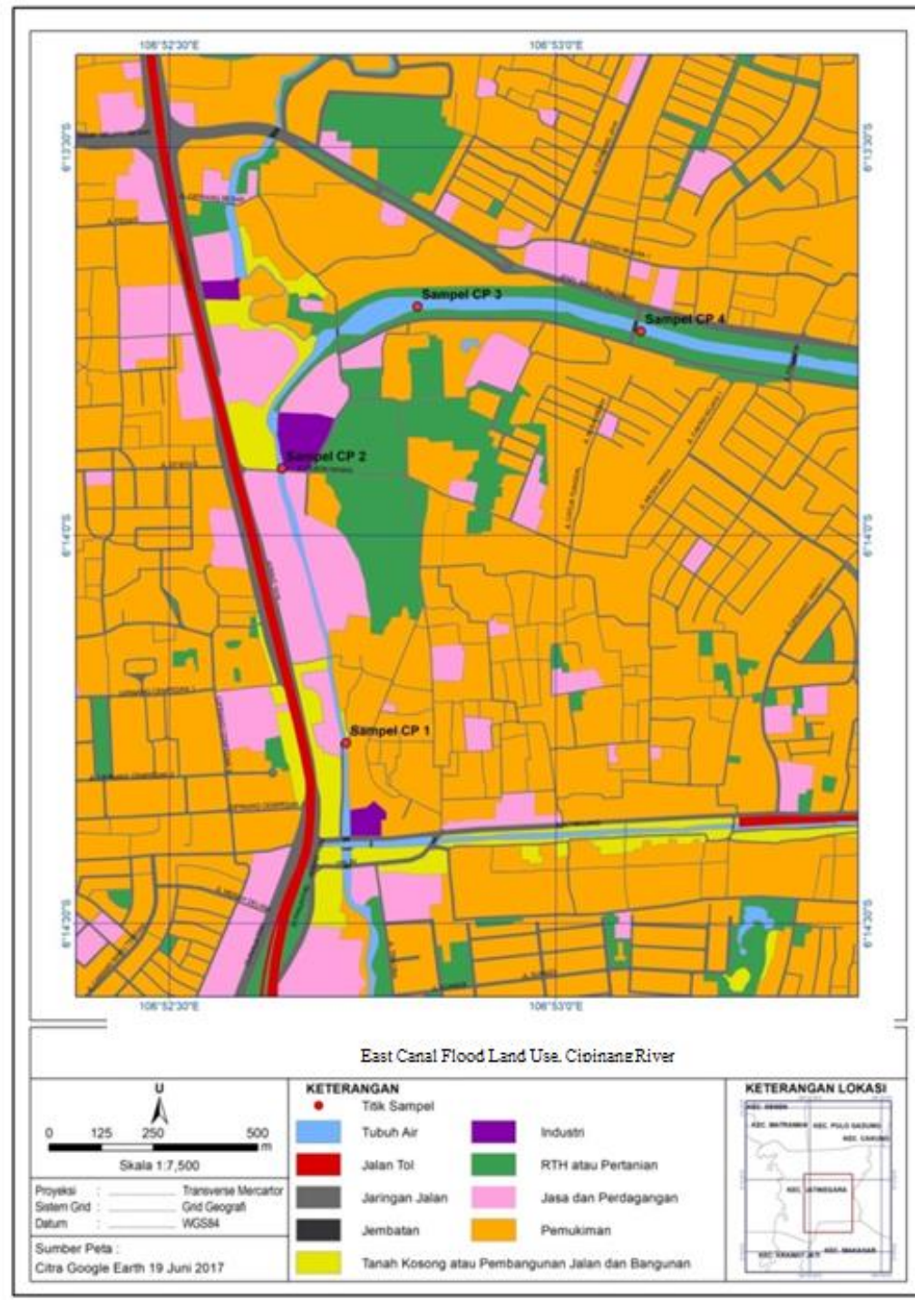

Fig. 1. Land use of East Canal Flood, 2017

Based on field observations, socio-economic factors influence land use in the upstream area of BKT. Space and land needs are determined by the socio-economic nature of the population. The necessities of life for shelter and other public interests have an effect on changes in the function of land around the river banks. Diverse anthropogenic activities upstream of BKT, including population work in industry, trade and services, increase land use conversion which results in a decrease in the quality of upstream BKT water. Human intervention on land has an impact on the environment and tends to change the hydrological nature of a watershed. Socio-economic conditions affecting land use in the upper reaches of the BKT river in accordance with the research of [9] which revealed that changes in land use due to interference by human socio-economic activities will change the environment, the hydrological nature of rivers (river water quality). 


\subsection{Physical factors affecting water quality of BKT}

Based on laboratory tests, there were seven water quality parameters of BKT that exceeded the quality standard of Government Regulation 82 of 2001 class I and II (see Table 3).

Table 3. Upstream Water Quality of East Flood Canal River (Cipinang River), 2018

\begin{tabular}{|c|c|c|c|c|c|c|c|c|c|}
\hline \multirow[t]{2}{*}{ No. } & \multirow{2}{*}{ Parameters } & \multirow[t]{2}{*}{ Unit } & \multicolumn{4}{|c|}{ Sample } & \multirow[t]{2}{*}{ Average } & \multicolumn{2}{|c|}{$\begin{array}{l}\text { GR } 82 \text { year } \\
2001\end{array}$} \\
\hline & & & CP1 & CP2 & CP3 & CP4 & & Class I & Class II \\
\hline 1 & BOD & $\mathrm{mg} / \mathrm{L}$ & 4.40 & 4.40 & 4.60 & 4.40 & 4.45 & 2 & 3 \\
\hline 2 & COD & $\mathrm{mg} / \mathrm{L}$ & 75.06 & 84.07 & 84.93 & 89.23 & 83.32 & 10 & 25 \\
\hline 3 & Phospate & $\mathrm{mg} / \mathrm{L}$ & 0.505 & 0.569 & 0.746 & 0.646 & 0.62 & 0.2 & 0.2 \\
\hline 4 & Nitrite & $\mathrm{mg} / \mathrm{L}$ & 0.294 & 0.285 & 0.247 & 0.304 & 0.28 & 0.06 & 0.06 \\
\hline 5 & Ammonia & $\mathrm{mg} / \mathrm{L}$ & 0.514 & 0.533 & 0.537 & 1.157 & 0.69 & 0.5 & $(-)$ \\
\hline 6 & Total Coliform & $\begin{array}{c}\mathrm{MPN} / 100 \\
\mathrm{~mL}\end{array}$ & $\begin{array}{c}16,00 \\
0\end{array}$ & 9,200 & 16,000 & 54,000 & 23,800 & 1,000 & 5,000 \\
\hline 7 & Fecal Coli & $\begin{array}{l}\text { MPN/100 } \\
\mathrm{mL}\end{array}$ & 9,200 & 9,200 & 16,000 & 35,000 & 17,350 & 100 & 1,000 \\
\hline
\end{tabular}

High BOD parameters followed by phosphate and COD. In CP3, BOD and phosphate levels are $4.60 \mathrm{mg} / \mathrm{L}$ and $0.746 \mathrm{mg} / \mathrm{L}$. This is influenced by the diverted from the Ciliwung River, resulting in accumulation of waste that flows in the Cipinang river from various sources (domestic, industrial, and construction activities). The condition of waste originating from non-point sources has an impact on high phosphate in the upper waters of BKT. The main sources are domestic waste in the form of population (faeces) (blackwater), food waste from households (greywater), markets and agricultural activities from the upstream part of the Cipinang River BKT. The results of the study in accordance with the findings of [7] state that waters that are positively contaminated by E. coli are not suitable for consumption as drinking water. In addition, the high level of BOD also correlated with the increase in COD levels in the upper BKT, ie at the point CP2 to CP4. The location and presence of chemical pollutants, one of which comes from the cement plant (PT. Jayamix) causes high levels of COD at that point.

Population activity produces waste in the form of greywater and blackwater, and waste has an impact on the degradation of BKT's water quality as an ecosystem service. The point source waste source is mostly from domestic households, while non-point source waste is generated from service and trade activities around the river banks. This is in accordance with the literature which states that the composition of waste diversity that contaminates a waters in the form of grey water and black water can be generated from domestic activities (households) and various other socio-economic activities and has an impact on water quality as ecosystem services as well as the hydrological conditions of a watershed [4].

\section{Conclusions}

Based on the result of research indicate that water quality upstream of BKT is influenced by social economic factor and land use. The water quality data of the river shows several parameters of water quality exceeding the the quality standard of Government Regulation 82 of 2001 class I and II, that is BOD, COD, Phosphate, Nitrite, Fecal coli, and total Coliform. In general, the quality of river water upstream BKT can not 
be used as raw water for drinking water because it exceeds the quality standard, except with some technologies of water treatment.

\section{Acknowledgment}

The authors are thankful to staff members of Balai Besar Wilayah Sungai Ciliwung Cisadane (BBWSCC). This Research is funded by the Grant of Indexed International Publication for Final Project of Students/Publikasi Terindeks Internasional Untuk Tugas Akhir Mahasiswa (PITTA) Universitas Indonesia 2018 no. UN2.R3.1/HKP.05.00/2018.

\section{References}

1. Alwi, L. Assessment of the impact of land use dynamics in the Wanggu watershed on sedimentation in Kendari Bay. Dissertation. Bogor Agricultural University Postgraduate School. (2012)

2. Central Ciliwung Cisadane River Region (BBWSCC). Studies control of water quality and solid waste in the BKT system. (2013)

3. Colley, R.J.D. River water quality in New Zealand: an introduction and overview. River Water Quality: 432-447.(2013)

4. Musamba, E.B., Y.M. Nganga, E.K. Bon, R.A. Giliba. Impact of socio-economic activities around Lake Victoria: land use and land use changes in Musoma Municipality, Tanzania. J. of Hum. Ecol. 35 3: 143-154. (2011)

5. Suriawiria, U. Water in a healthy life and environment. Bandung. (2003)

6. Suwarno, L. Ika, Sugiyono. The basics of education. Yogyakarta. (2014)

7. Tafangenyasha, C., T. Dzinomwa. Land use in the Lowveld Sand River in South-East Zimbabwe. Land Use and Water Resource. (2005) 